\title{
PENGARUH PENERAPAN STANDAR AUDITING DAN ETIKA PROFESI AUDITOR TERHADAP RELIABILITAS LAPORAN AUDIT (Studi Empiris pada Kantor Akuntan Publik di Wilayah Jakarta Selatan)
}

\author{
Oleh: \\ Indira Shinta Dewi \\ Yulianti Putri Wulandari \\ Progam Studi Akuntansi Fakultas Ekonomi \\ Universitas Satya Negara Indonesia
}

\begin{abstract}
The aim of this research was to identify and analyze the effect of the application of auditing standards and professional ethics of auditors to the reliability of the audit report. The population in this research is the auditors who work at Public Accounting Firm in South Jakarta with a sample taken using purposive sampling method with an analysis tool used was SPSS version 21.0, and the number of respondents as many as 70 of 11 Public Accounting Firm . The data used in this research are categorized as primary data. Data were collected through questionnaires. Testing data using multiple linear regression analysis. The independent variable in this research is the application of auditing standards and professional ethics of auditors while the dependent variable is the reliability of the audit report.

Based on the results of this research show that: 1) The application of auditing standards have a significantly effect and positive value to the reliability of the audit report; 2) The professional ethics of auditors does not have a significantly effect but have a positive value to the reliability of the audit report; 3) The application of auditing standards and professional ethics of auditors simultaneously have a significant effect and positive value to the reliability of the audit report.

Keywords: Application Auditing Standards; Auditor Professional Ethics; Reliability Audit Report.
\end{abstract}

\begin{abstract}
ABSTRAK
Tujuan dari penelitian ini adalah untuk mengetahui dan menganalisa pengaruh penerapan standar auditing dan etika profesi auditor terhadap reliabilitas laporan audit. Populasi dalam penelitian ini adalah auditor yang bekerja pada Kantor Akuntan Publik di wilayah Jakarta Selatan dengan sampel penelitian diambil menggunakan metode purposive sampling dengan menggunakan alat analisis SPSS versi 21.0. Jumlah responden sebanyak 70 dari 11 Kantor Akuntan Publik. Data yang digunakan dalam penelitian ini dikatagorikan sebagai data primer. Data dikumpulkan melalui penyebaran kuesioner. Pengujian data dilakukan dengan menggunakan alat analisis regresi linier berganda. Variabel independen dalam penelitian ini adalah penerapan standar auditing dan etika profesi auditor sedangkan variabel dependennya adalah reliabilitas laporan audit. Berdasarkan hasil penelitian ini, menunjukkan bahwa: 1) Penerapan standar auditing berpengaruh secara signifikan dan memiliki nilai positif terhadap reliabilitas laporan audit; 2) Etika profesi auditor tidak berpengaruh secara signifikan namun memiliki nilai positif terhadap reliabilitas laporan audit , 3)Apakah penerapan standar auditing dan etika profesi auditor secara simultan berpengaruh terhadap reliabilitas laporan audit? Kata Kunci : Penerapan Standar Auditing; Etika Profesi Auditor; Reliabilitas Laporan Audit.
\end{abstract}




\section{Latar Belakang}

\section{PENDAHULUAN}

Globalisasi telah menyebabkan perkembangan yang besar dalam bidang ekonomi di Indonesia. Perkembangan dalam bidang ekonomi pada gilirannya menuntut adanya profesionalisme pendukung. Salah satu profesi yang mendukung dalam bidang ekonomi dewasa ini adalah profesi akuntan publik terutama auditor. Profesi akuntan publik dikenal oleh masyarakat dari jasa audit yang disediakan bagi pemakai informasi keuangan. Timbul dan berkembangnya profesi akuntan publik disuatu negara adalah sejalan dengan berkembangnya perusahaan dan berbagai bentuk badan hukum perusahaan di negara tersebut.

Manajemen perusahaan memerlukan jasa pihak ketiga agar pertanggungjawaban laporan keuangan yang disajikan kepada pihak luar dapat dipercaya, sedangkan pihak luar perusahaan memerlukan jasa pihak ketiga untuk memperoleh keyakinan bahwa laporan keuangan yang disajikan oleh manajemen perusahaan dapat dipercaya sebagai dasar keputusan-keputusan yang diambil oleh mereka. Baik manajemen perusahaan maupun pihak luar perusahaan yang berkepentingan terhadap perusahaan memerlukan jasa pihak ketiga yang dapat dipercaya (Mulyadi, 2002:2-3).

Menggunakan jasa audit yang disediakan oleh Akuntan publik menghasilkan laporan yang dapat memiliki sifat reliabilitas (keandalan) yaitu laporan keuangan auditan yang dihasilkan dapat diverifikasi melalui kertas kerja auditor yang merupakan catatan-catatan yang diselenggarakan oleh auditor tentang prosedur audit yang ditempuhnya, pengujian yang dilakukannya, informasi yang diperolehnya, dan simpulan yang dibuatnya sehubungan dengan auditnya (IAPI, 2011:339.2).

Laporan audit hendaknya juga disajikan secara jujur sesuai kondisi yang sebenarnya serta tepat berdasarkan Standar Akuntansi Keuangan di Indonesia. Selain itu laporan audit harus bersifat netral yang berarti informasi tersebut tidak ditujukan untuk kepentingan pihak tertentu. Sehingga reliabilitas atas suatu laporan audit inilah yang dapat memberi kepercayaan bagi pihak luar perusahaan bahwa laporan keuangan yang telah diaudit tersebut benar disajikan sesuai dengan kondisi perusahaan sebenarnya.

Salah satu tipe standar profesi yang dikodifikasi dalam Standar Profesional Akuntan Publik yaitu standar auditing yang merupakan standar mutu dan kinerja auditor dalam menjalankan penugasan auditnya. Standar auditing tersebut memuat tentang standar umum yang menekankan pada pentingnya kualitas pribadi yang harus dimiliki auditor, standar pekerjaan lapangan menyangkut pengumpulan bukti dan aktivitas lain selama pelaksanaan audit yang sebenarnya dan standar pelaporan yang mengharuskan auditor menyajikan laporan keuangan secara keseluruhan, termasuk pengungkapan informatif dan pernyataan apakah laporan keuangan telah disajikan sesuai dengan prinsip-prinsip akuntansi yang berlaku umum serta menunjukkan atau menyatakan jika ada, keadaan dimana prinsip akuntansi yang berlaku umum di Indonesia (Generally Accepted Accounting Principle - GAAP) tidak diterapkan secara konsisten dalam tahun berjalan jika dibandingkan dengan tahun sebelumnya. 
Disamping itu, tipe standar profesi lainnya yang dikodifikasi di dalam SPAP adalah kode etik profesi. Salah satu hal yang membedakan etika profesi akuntan publik dengan profesi lainnya adalah tanggung jawab profesi akuntan publik dalam melindungi kepentingan publik. Oleh karena itu, tanggung jawab profesi akuntan publik tidak hanya terbatas pada kepentingan klien atau pemberi kerja. Ketika bertindak untuk kepentingan publik, setiap praktisi harus mematuhi dan menerapkan seluruh prinsip dasar dan kode etik yang telah diatur dalam Standar Profesi Akuntan Publik (IAPI, 2011:1)

Kasus yang terjadi pada PT Kereta Api Indonesia (PT KAI) merupakan salah satu contoh kasus terkait pelanggaran standar profesi akuntan publik dan etika profesi. Dimana dalam pelaporan kinerja keuangan tahunan PT KAI yang diterbitkan tahun 2005, diumumkan bahwa PT KAI mendapat keuntungan sebesar Rp 6,9 Milyar. Padahal sebenarnya mengalami kerugian sebesar Rp 63 Milyar. Hal ini disebabkan karena terjadi kesalahan dalam pencatatan pada beberapa akun dalam laporan keuangan PT KAI tersebut. Dalam hal ini tentunya apabila standar profesi akuntan publik dan etika profesi auditor diterapkan dengan baik, maka auditor yang melakukan penugasan audit seharusnya dapat mengetahui adanya kekeliruan dalam pencatatan transaksi atau perubahan tersebut.

Berdasarkan uraian dan fenomena di atas, maka peneliti tertarik untuk menarik judul penelitian "Pengaruh penerapan standar auditing dan etika profesi auditor terhadap reliabilitas laporan audit".

\section{Perumusan Masalah}

Berdasarkan latar belakang penelitian yang telah dikemukakan, maka peneliti merumuskan masalah sebagai berikut :

1. Apakah penerapan standar auditing berpengaruh terhadap reliabilitas laporan Audit?

2. Apakah etika profesi auditor berpengaruh terhadap reliabilitas laporan audit?

3. Apakah penerapan standar auditing dan etika profesi auditor secara simultan berpengaruh terhadap reliabilitas laporan audit?

\section{Tujuan Penelitian}

Berdasarkan perumusan masalah yang telah diuraikan di atas, maka tujuan yang ingin dicapai dalam penelitian ini adalah :

1. Untuk mengetahui bagaimana pengaruh penerapan standar auditing terhadap reliabilitas laporan audit.

2. Untuk mengetahui bagaimana pengaruh etika profesi auditor terhadap reliabilitas laporan audit.

3. Untuk mengetahui bagaimana pengaruh penerapan standar auditing dan etika profesi auditor secara simultan terhadap reliabilitas laporan audit. 


\section{Auditing}

\section{LANDASAN TEORI}

Definisi auditing menurut Agoes Sukrisno, (2012:4) adalah sebagai berikut:

Suatu pemeriksaan yang dilakukan secara kritis dan sistematis oleh pihak yang independen, terhadap laporan keuangan yang telah disusun oleh manajemen, beserta catatan-catatan pembukuan dan bukti-bukti pendukungnya, dengan tujuan untuk dapat memberikan pendapat mengenai kewajaran laporan keuangan tersebut.

\section{Standar Auditing Definisi standar Auditing}

Standar audit merupakan pedoman umum untuk membantu auditor memenuhi tanggung jawab profesionalnya dalam audit atas laporan keuangan historis. Standar ini mencakup pertimbangan mengenai kualitas profesional seperti kompetensi dan independensi, persyaratan laporan dan bukti (Arens et.al, 2013:41).

\section{Standar Auditing}

Standar auditing yang telah ditetapkan dan disahkan oleh Institut Akuntan Publik Indonesia dalam SA Seksi 150 dalam Standar Profesional Akuntan Publik (IAPI, 2011:150.1) adalah sebagai berikut:

\section{A. Standar Umum}

1. Audit harus dilaksanakan oleh seorang atau lebih yang memiliki keahlian dan pelatihan teknis yang cukup sebagai auditor.

2. Dalam semua hal yang berhubungan dengan perikatan, independensi dalam sikap mental harus dipertahankan oleh auditor.

3. Dalam pelaksanaan audit dan penyusunan laporannya, auditor wajib menggunakan kemahiran profesionalnya dengan cermat dan seksama.

\section{B. Standar Pekerjaan Lapangan}

1. Pekerjaan harus direncanakan sebaik-baiknya dan jika digunakan asisten harus disupervisi dengan semestinya.

2. Pemahaman memadai atas pengendalian intern harus diperoleh untuk merencanakan audit dan menentukan sifat, saat dan lingkup pengujian yang akan dilakukan.

3. Bukti audit kompeten yang cukup harus diperoleh melalui inspeksi, pengamatan, permintaan keterangan dan konfirmasi sebagai dasar memadai untuk menyatakan pendapat atas laporan keuangan yang diaudit. 


\section{Standar Pelaporan}

1. Laporan auditor harus menyatakan apakah laporan keuangan telah disusun sesuai dengan Standar Akuntansi Keuangan di Indonesia

2. Laporan auditor harus menunjukkan atau menyatakan, jika ada, ketidakkonsistenan penerapan prinsip akuntansi dalam penyusunan laporan keuangan periode berjalan dengan penerapan akuntansi tersebut dalam periode sebelumnya.

3. Pengungkapan informatif dalam laporan keuangan harus dipandang memadai, kecuali dinyatakan lain dalam laporan auditor.

4. Laporan keuangan auditor harus memuat suatu pernyataan pendapat mengenai laporan keuangan secara keseluruhan atau suatu asersi bahwa pernyataan demikian tidak dapat diberikan. Jika pendapat secara keseluruhan tidak dapat diberikan, maka alasannya harus dinyatakan. Dalam hal nama auditor dikaitkan dengan laporan keuangan, maka laporan auditor harus memuat petunjuk yang jelas mengenai sifat pekerjaan audit yang dilaksanakan, jika ada, dan tingkat tanggungjawab yang dipikul oleh auditor.

\section{Etika Profesi Auditor Definisi Etika Profesi}

Menurut IAPI (2011:1) dalam prinsip-prinsip dasar etika profesi Seksi 100, salah satu hal yang membedakan etika profesi akuntan publik dengan profesi lainnya adalah tanggung jawab profesi akuntan publik dalam melindungi kepentingan publik. Oleh karena itu, tanggung jawab profesi akuntan publik tidak hanya terbatas pada kepentingan klien atau pemberi kerja. Ketika bertindak untuk kepentingan publik, setiap praktisi harus mematuhi dan menerapkan seluruh prinsip dasar dan kode etik yang telah diatur dalam kode etik.

\section{Prinsip Dasar Etika Profesi}

\section{A. Prinsip Dasar:}

\section{Prinsip Integritas.}

Setiap praktisi harus tegas dan jujur dalam menjalin hubungan profesional dan bisnis dalam melaksanakan pekerjaan.

2. Prinsip Obyektifitas.

Setiap praktisi tidak boleh membiarkan subyektifitas, benturan kepentingan, atau pengaruh yang tidak layak (undue influence) dari pihak-pihak lain mempengaruhi pertimbangan profesional atau pertimbangan bisnisnya.

3. Prinsip Kompetensi Serta Sikap Kecermatan dan Kehati-hatian Profesional (professional competence and due care).

Setiap praktisi wajib memelihara pengetahuan dan keahlian profesionalnya pada suatu tingkatan yang dipersyaratkan secara berkesinambungan, sehingga klien atau pemberi kerja dapat menerima jasa profesional yang diberikan secara kompeten berdasarkan perkembangan terkini dalam praktik, perundang-undangan, dan metode pelaksanaan pekerjaan. Setiap praktisi harus bertindak secara profesional 
dan sesuai dengan standar profesi dan kode etik profesi yang berlaku dalam memberikan jasa profesionalnya.

\section{Prinsip Kerahasiaan.}

Setiap praktisi wajib menjaga kerahasiaan informasi yang diperoleh sebagai hasil dari hubungan profesional dan hubungan bisnisnya, serta tidak boleh mengungkapkan informasi tersebut kepada pihak ketiga tanpa persetujuan dari klien atau pemberi kerja, kecuali jika terdapat kewajiban untuk mengungkapkan sesuai dengan ketentuan hukum atau peraturan lainnya yang berlaku. Informasi rahasia yang diperoleh dari hubungan profesional dan hubungan bisnis tidak boleh digunakan oleh praktisi untuk keuntungan pribadinya atau pihak ketiga.

\section{Prinsip Perilaku Profesional.}

Setiap praktisi wajib mematuhi hukum dan peraturan yang berlaku dan harus menghindari semua tindakan yang dapat mendiskreditkan profesi.

\section{B. Pendekatan Kerangka Konseptual}

Kerangka konseptual mengharuskan praktisi untuk mengidentifikasi, mengevaluasi dan menangani setiap ancaman terhadap kepatuhan pada prinsip dasar etika profesi dengan tujuan untuk melindungi kepentingan publik, serta tidak hanya mematuhi seperangkat peraturan khusus yang dapat bersifat subjektif.

\section{Ancaman dan Pencegahan}

Kepatuhan pada prinsip dasar etika profesi dapat terancam oleh berbagai situasi. Ancaman tersebut dapat diklasifikasikan sebagai berikut:

1. Ancaman kepentingan pribadi; yaitu ancaman yang terjadi sebagai akibat dari kepentingan keuangan, maupun kepentingan lainnya dari praktisi maupun anggota keluarga langsung atau anggota keluarga dekat dengan praktisi.

2. Ancaman telaah pribadi; yaitu ancaman yang terjadi ketika pertimbangan yang diberikan sebelumnya harus dievaluasi kembali oleh praktisi yang bertanggung jawab atas pertimbangan tersebut.

3. Ancaman advokasi; yaitu ancaman yang terjadi ketika praktisi menyatakan sikap atau pendapat mengenai suatu hal yang dapat mengurangi obyektifitas selanjutnya dari praktisi tersebut.

4. Ancaman kedekatan; yaitu ancaman yang terjadi ketika praktisi terlalu bersimpati terhadap kepentingan pihak lain sebagai akibat dari kedekatan hubungannya.

5. Ancaman intimidasi; yaitu ancaman yang terjadi ketika praktisi dihalangi untuk bersikap obyektif.

Sedangkan pencegahan yang dapat menghilangkan ancaman tersebut atau menguranginya ke tingkat yang dapat diterima diklasifikasikan sebagai berikut:

1. Pencegahan yang dibuat oleh profesi, perundang-undangan, atau peraturan.

2. Pencegahan dalam lingkungan kerja. 


\section{Penyelesaian Masalah Yang Terkait Dengan Etika Profesi}

Ketika memulai proses penyelesaian masalah yang terkait dengan etika profesi, baik secara formal maupun informal, setiap praktisi baik secara individu maupun bersama-sama dengan koleganya, harus mempertimbangkan hal-hal sebagai berikut:

1. Fakta yang relevan.

2. Masalah etika profesi yang terkait.

3. Prinsip dasar etika profesi yang terkait dengan masalah etika profesi yang dihadapi.

4. Prosedur internal yang berlaku.

5. Tindakan alternatif.

\section{Laporan Audit \\ Definisi Laporan Audit}

Laporan audit merupakan media yang dipakai oleh auditor dalam berkomunikasi dengan masyarakat dan lingkungannya. Dalam laporan tersebut auditor menyatakan pendapatnya mengenai kewajaran laporan keuangan auditan (Mulyadi, 2002:12).

\section{Reliabilitas Laporan Audit}

Menurut Stice et.al, (2009:30-31) Informasi dikatakan dapat diandalkan apabila secara relatif bebas dari kesalahan dan menyajikan hal yang seharusnya. Keandalan (reliability) tidak berarti ketepatan yang absolut, informasi yang berdasarkan penilaian dan yang menggunakan estimasi dan perkiraan tidak mungkin akurat secara total, tetapi harus dapat diandalkan. Tujuannya adalah memberikan jenis informasi yang dapat memberikan kepercayaan bagi pemakainya. Informasi seperti ini harus memiliki kriteria sebagai berikut:

a. Dapat diverifikasi (verifiability)

b. Penyajian jujur (representational faithfulness)

c. Netralitas (neutrality)

Berdasarkan pengertian mengenai keandalan (reliability) laporan keuangan diatas, peneliti mengasumsikan bahwa pada prinsipnya keandalan yang dimiliki oleh laporan audit sama dengan laporan keuangan sehingga agar laporan audit dapat dikatakan memiliki keandalan (reliability) maka laporan audit harus memiliki kriteria yang sama seperti dengan kriteria yang harus dimiliki oleh laporan keuangan yaitu:

a. Dapat diverifikasi (verifiability); maksudnya laporan audit harus dapat diverifikasi atau ditelusuri melalui kertas kerja auditor. Jika terdapat pemeriksaan oleh pihak lain dengan menggunakan metode yang sama maka hasil yang didapatkan akan serupa.

b. Penyajian jujur (representational faithfulness); maksudnya laporan audit yang dihasilkan hendaknya sesuai dengan keadaan perusahaan yang sebenarnya. 
c. Netralitas; maksudnya laporan audit yang dihasilkan tidak ditujukan untuk kepentingan pihak tertentu. Informasi yang disajikan di dalamnya harus faktual, benar, dan bersifat obyektif.

\section{METODOLOGI PENELITIAN}

\section{Metode Pengumpulan Data}

Penelitian ini merupakan penelitian kausal yang dilakukan selama 3 bulan pada KAP di wilayah Jakarta Selatan. Data yang digunakan merupakan data primer yang diperoleh melalui penyebaran kuesioner.

Skala yang digunakan dalam penelitian untuk pembobotan item kuesioner adalah menggunakan skala Likert.

\section{Populasi dan Sampel}

Populasi penelitian adalah semua auditor yang ada di Wilayah Jakarta Selatan. Pengambilan sampel dilakukan dengan cara purposive sampling. Auditor yang dijadikan sampling adalah auditor yang telah memiliki pengalaman minimal 1 (Satu) tahun, hal ini dilakukan karena auditor tersebut telah memahami pekerjaan audit, kertas kerja audit dan telah beradaptasi dengan lingkungan kerja.

\section{Hipotesis Penelitian}

Pengujian hipotesis bertujuan untuk mengetahui pengaruh penerapan standar audit dan etika profesi auditor terhadap reliabilitas laporan audit. Adapun hipotesis yang akan diuji adalah sebagai berikut :

$\mathrm{Ho}_{1}$ : Tidak terdapat pengaruh penerapan standar auditing terhadap reliabilitas laporan audit.

$\mathrm{Ha}_{1}$ : Terdapat pengaruh penerapan standar auditing terhadap reliabilitas laporan audit.

$\mathrm{Ho}_{2}$ : Tidak terdapat pengaruh etika profesi auditor terhadap reliabilitas laporan audit.

$\mathrm{Ha}_{2}$ : Terdapat pengaruh etika profesi auditor terhadap reliabilitas laporan audit.

$\mathrm{Ho}_{3}$ : Tidak terdapat pengaruh penerapan standar auditing dan etika profesi auditor terhadap reliabilitas laporan audit.

$\mathrm{Ha}_{3}$ : Terdapat pengaruh penerapan standar auditing dan etika profesi auditor terhadap reliabilitas laporan audit.

\section{Kerangka Pemikiran}

Berdasarkan uraian pada bab sebelumnya serta jurnal ilmiah yang ada maka peneliti memutuskan dan menetapkan kerangka penelitian untuk melakukan penelitian untuk menelaah kenyataan di lapangan dengan obyek penelitian yaitu seluruh auditor yang bekerja di Kantor Akuntan Publik (KAP) di wilayah Jakarta Selatan. Adapun kerangka pemikiran tersebut dapat digambarkan dalam sebuah model berikut : 
Variabel Independen

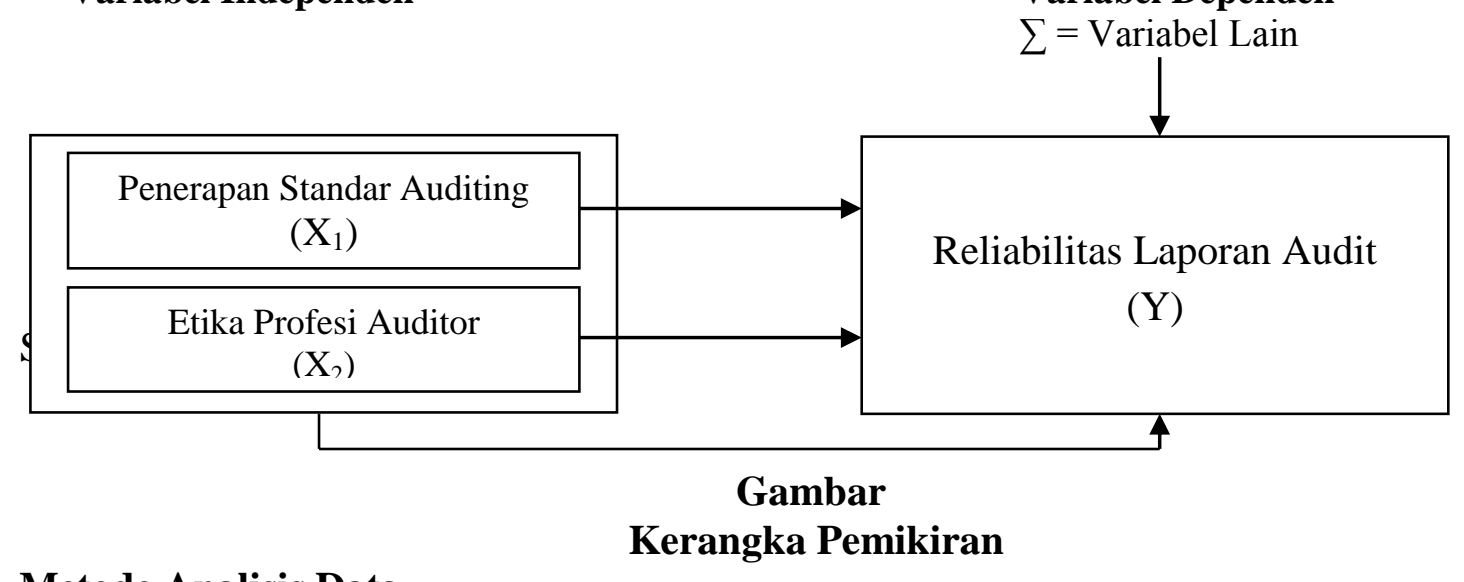

\section{Metode Analisis Data}

Penelitian ini menggunakan alat analisis regresi dan uji asumsi klasik. Pengujian hipotesis dilakukan dengan uji t dan uji F.

Berikut ini adalah persamaan yang digunakan dalam analisi regresi dalam penelitian:

$\mathrm{Y}=\alpha+\beta_{1} \mathrm{X}_{1}+\beta_{2} \mathrm{X}_{2}+\varepsilon$

Keterangan :

Y : Reliabilitas laporan audit

$\alpha$ : Nilai konstanta nilai $Y$ jika $X=0$

$\beta$ : Nilai arah sebagai penentu ramalan (prediksi) yang menunjukan nilai peningkatan

$(+)$ atau penurunan (-) $\mathrm{Y}$

$\mathrm{X}_{1}$ : Penerapan standar auditing

$\mathrm{X}_{2}$ : Etika Profesi Auditor

$\varepsilon$ : Variabel lain yang mempengaruhi $\mathrm{Y}$

1) Uji t

Kemudian untuk pengujian hipotesis diuji dengan menggunakan uji t dan uji F:

$\mathrm{Ho}_{1}$ : Tidak terdapat pengaruh penerapan standar auditing terhadap reliabilitas laporan audit.

$\mathrm{Ha}_{1}$ : Terdapat pengaruh penerapan standar auditing terhadap reliabilitas laporan audit.

$\mathrm{Ho}_{2}$ : Tidak terdapat pengaruh etika profesi auditor terhadap reliabilitas laporan audit.

$\mathrm{Ha}_{2}$ : Terdapat pengaruh etika profesi auditor terhadap reliabilitas laporan audit.

Hasil perhitungan $\left(\mathrm{t}_{\text {hitung }}\right)$ kemudian dibandingkan dengan nilai $\left(\mathrm{t}_{\text {tabel }}\right)$ dengan tingkat keyakinan $95 \%(\alpha=0,05)$ dengan kriteria keputusan:

Jika $\mathrm{t}_{\text {hitung }}<\mathrm{t}_{\text {tabel: }}$ H0 diterima Ha ditolak.

Jika $t_{\text {hitung }}>t_{\text {tabel }}: \mathrm{H} 0$ ditolak Ha diterima. 
2) Uji F

$\mathrm{Ho}_{3}$ : Tidak terdapat pengaruh penerapan standar auditing dan etika profesi auditor terhadap reliabilitas laporan audit.

$\mathrm{Ha}_{3}$ : Terdapat pengaruh penerapan standar auditing dan etika profesi auditor terhadap reliabilitas laporan audit.

Hasil perhitungan $\left(\mathrm{F}_{\text {hitung }}\right)$ kemudian dibandingkan dengan nilai $\left(\mathrm{F}_{\text {tabel }}\right)$ dengan tingkat keyakinan $95 \%(\alpha=0,05)$ dengan kriteria keputusan:

Jika $\mathrm{F}_{\text {hitung }}<\mathrm{F}_{\text {tabel }}$ : $\mathrm{H} 0$ diterima Ha ditolak.

Jika $\mathrm{F}_{\text {hitung }}>\mathrm{F}_{\text {tabel }}$ : $\mathrm{H} 0$ ditolak Ha diterima.

Selanjutnya untuk uji Koefisien Determinasi $\left(\mathrm{R}^{2}\right)$ pada intinya mengukur seberapa jauh kemampuan model dalam menerangkan variasi variabel dependen. Dalam uji koefisien determinasi dapat diketahui dengan melihat hasil uji SPSS pada tabel Model Summary.

\section{ANALISIS HASIL DAN PEMBAHASAN}

\section{Uji Reliabilitas}

\section{Uji Reliabilitas Variabel Penerapan Standar Auditing (X1)}

Hasil olah data untuk uji reliabilitas variabel penerapan standar auditing disajikan dalam tabel sebagai berikut:

\section{Hasil Uji Reliabilitas Penerapan Standar Auditing Reliability Statistics}

\begin{tabular}{|r|r|r|}
\hline Cronbach's Alpha & $\begin{array}{c}\text { Cronbach's Alpha } \\
\text { Based on } \\
\text { Standardized } \\
\text { Items }\end{array}$ & N of Items \\
\hline, 722 &, 783 & 11 \\
\hline
\end{tabular}

Sumber: Data output SPSS 21, 2016.

Tabel diatas menunjukkan Cronbach's Alpha Based on Standardized Items 0,783 > 0,70 . Hal ini dapat disimpulkan bahwa pernyataan-pernyataan dalam variabel penerapan standar auditing adalah reliabel, artinya bahwa hasil pengukuran variabel penerapan standar auditing adalah konsisten.

\section{Uji Reliabilitas Variabel Etika Profesi Auditor (X2)} berikut:

Hasil olah data untuk uji reliabilitas variabel etika profesi auditor disajikan dalam tabel 
Reliability Statistics

\begin{tabular}{|r|r|r|}
\hline $\begin{array}{c}\text { Cronbach's } \\
\text { Alpha }\end{array}$ & $\begin{array}{c}\text { Cronbach's } \\
\text { Alpha Based on } \\
\text { Standardized } \\
\text { Items }\end{array}$ & N of Items \\
\hline, 722 &, 834 & 21 \\
\hline
\end{tabular}

Sumber: Data output SPSS 21, 2016.

Berdasarkan table diatas menunjukkan Cronbach's Alpha Based on Standardized Items $0,834>0,70$. Dapat disimpulkan bahwa pernyataan-pernyataan dalam variabel etika profesi auditor adalah reliabel, artinya bahwa hasil pengukuran variabel etika profesi auditor konsisten.

\section{Uji Reliabilitas Variabel Reliabilitas Laporan Audit (Y)}

Hasil olah data untuk uji reliabilitas variabel reliabilitas laporan audit disajikan dalam tabel berikut :

\section{Hasil Uji Reliabilitas Laporan Audit Reliability Statistics}

\begin{tabular}{|r|r|r|}
\hline $\begin{array}{c}\text { Cronbach's } \\
\text { Alpha }\end{array}$ & $\begin{array}{c}\text { Cronbach's } \\
\text { Alpha Based } \\
\text { on } \\
\text { Standardized } \\
\text { Items }\end{array}$ & N of Items \\
\hline, 763 &, 762 & 4 \\
\hline
\end{tabular}

Sumber: Data output SPSS 21, 2016.

Berdasarkan Tabel menunjukkan Cronbach's Alpha Based on Standardized Items $0,762>0,70$. Dapat disimpulkan bahwa pernyataan-pernyataan dalam variabel reliabilitas laporan audit adalah reliabel, artinya bahwa hasil pengukuran variabel reliabilitas laporan audit adalah konsisten.

\section{Ringkasan Uji Reliabilitas Variabel X dan Y}

Ringkasan uji reliabilitas terhadap variabel penerapan standar auditing, etika profesi auditor, dan reliabilitas laporan audit disajikan dalam tabel berikut:

\section{Ringkasan Reliability Statistics}

\begin{tabular}{|c|c|c|c|}
\hline No & Variabel & $\begin{array}{c}\text { Cronbach's Alpha Based } \\
\text { on Standardized Items }\end{array}$ & Kesimpulan \\
\hline 1 & $\begin{array}{c}\text { Penerapan Standar } \\
\text { Auditing }\end{array}$ &, 783 & Reliabel \\
\hline
\end{tabular}




\begin{tabular}{|c|c|c|c|}
\hline 2 & $\begin{array}{c}\text { Etika Profesi } \\
\text { Auditor }\end{array}$ &, 834 & Reliabel \\
\hline 3 & $\begin{array}{c}\text { Reliabilitas Laporan } \\
\text { Audit }\end{array}$ &, 762 & Reliabel \\
\hline
\end{tabular}

Sumber: Data output SPSS 21, 2016

Berdasarkan Tabel 4.10 menunjukkan Cronbach's Alpha Based On Standardized Items $>0,70$. Dapat disimpulkan bahwa pernyataan-pernyataan dalam variabel penerapan standar auditing, etika profesi auditor dan reliabilitas laporan audit adalah reliabel, artinya bahwa hasil pengukuran variabel-variabel tersebut adalah konsisten.

\section{Uji Validitas}

\section{Uji Validitas Variabel Penerapan Standar Auditing (X1)}

Hasil olah data untuk uji validitas untuk penerapan standar auditing dapat disajikan pada tabel berikut :

Hasil Uji Validitas Penerapan Standar Auditing Item-Total Statistics

\begin{tabular}{|l|r|r|r|r|}
\hline & $\begin{array}{c}\text { Scale } \\
\text { Mean if } \\
\text { Item } \\
\text { Deleted }\end{array}$ & $\begin{array}{c}\text { Scale } \\
\text { Variance if } \\
\text { Item } \\
\text { Deleted }\end{array}$ & $\begin{array}{c}\text { Corrected } \\
\text { Item-Total } \\
\text { Correlation }\end{array}$ & $\begin{array}{c}\text { Cronbach's } \\
\text { Alpha if } \\
\text { Item } \\
\text { Deleted }\end{array}$ \\
\hline P1_PSA & 78,557 & 49,989 &, 581 &, 694 \\
P2_PSA & 78,643 & 50,291 &, 460 &, 700 \\
P3_PSA & 78,714 & 51,946 &, 276 &, 715 \\
P4_PSA & 78,629 & 52,643 &, 299 &, 715 \\
P5_PSA & 78,757 & 48,998 &, 588 &, 689 \\
P6_PSA & 78,657 & 50,663 &, 457 &, 701 \\
P7_PSA & 78,757 & 48,331 &, 604 &, 685 \\
P8_PSA & 78,700 & 50,213 &, 460 &, 699 \\
P9_PSA & 78,586 & 53,406 &, 356 &, 715 \\
P10_PSA & 78,600 & 52,128 &, 345 &, 711 \\
Penerapan Standar & 41,400 & 13,983 & 1,000 &, 695 \\
Auditing & & & & \\
\hline
\end{tabular}

Sumber: Data output SPSS 21, 2016.

Berdasarkan hasil output SPSS di atas, dapat dijelaskan bahwa kolom Corrected ItemTotal Correlation merupakan $\mathrm{r}$ hitung untuk masing-masing item atas butir pernyataan. Menunjukkan bahwa semua butir pernyataan yaitu pernyataan 1 - 10 dinyatakan valid dan tidak ada butir pernyataan yang dihilangkan karena semua butir pernyataan benar memiliki $r$ hitung > r tabel. 


\section{Uji Validitas Variabel Etika Profesi Auditor (X2)}

Hasil olah data untuk uji validitas untuk etika profesi auditor dapat disajikan pada tabel sebagai berikut :

\section{Hasil Uji Validitas Etika Profesi Auditor} Item-Total Statistics

\begin{tabular}{|l|r|r|r|r|}
\hline & $\begin{array}{c}\text { Scale Mean } \\
\text { if Item } \\
\text { Deleted }\end{array}$ & $\begin{array}{c}\text { Scale } \\
\text { Variance if } \\
\text { Item Deleted }\end{array}$ & $\begin{array}{c}\text { Corrected } \\
\text { Item-Total } \\
\text { Correlation }\end{array}$ & $\begin{array}{c}\text { Cronbach's } \\
\text { Alpha if Item } \\
\text { Deleted }\end{array}$ \\
\hline P1_EPA & 160,657 & 118,692 &, 342 &, 713 \\
P2_EPA & 160,957 & 118,853 &, 253 &, 715 \\
P3_EPA & 160,714 & 117,453 &, 413 &, 710 \\
P4_EPA & 160,700 & 117,981 &, 387 &, 711 \\
P5_EPA & 160,771 & 117,918 &, 410 &, 711 \\
P6_EPA & 160,857 & 119,226 &, 291 &, 715 \\
P7_EPA & 161,171 & 118,318 &, 340 &, 713 \\
P8_EPA & 160,886 & 117,726 &, 477 &, 710 \\
P9_EPA & 160,943 & 116,895 &, 511 &, 708 \\
P10_EPA & 161,057 & 115,127 &, 503 &, 704 \\
P11_EPA & 161,129 & 119,476 &, 271 &, 716 \\
P12_EPA & 160,771 & 117,135 &, 417 &, 709 \\
P13_EPA & 160,900 & 116,816 &, 383 &, 709 \\
P14_EPA & 160,900 & 120,120 &, 278 &, 716 \\
P15_EPA & 161,029 & 118,144 &, 387 &, 711 \\
P16_EPA & 160,829 & 117,188 &, 490 &, 708 \\
P17_EPA & 161,100 & 117,019 &, 467 &, 708 \\
P18_EPA & 160,957 & 116,679 &, 599 &, 706 \\
P19_EPA & 160,871 & 120,027 &, 360 &, 715 \\
P20_EPA & 160,857 & 116,878 &, 593 &, 707 \\
Etika Profesi & 82,514 & 30,920 & 1,000 &, 789 \\
Auditor & & & & \\
\hline
\end{tabular}

Sumber: Data output SPSS 21, 2016.

Berdasarkan hasil output SPSS di atas, dapat dijelaskan bahwa kolom Corrected ItemTotal Correlation merupakan $\mathrm{r}$ hitung untuk masing-masing item atau butir pernyataan. Dari analisis output di atas, menunjukkan bahwa semua butir pernyataan yaitu pernyataan $1-20$ dinyatakan valid dan tidak ada butir pernyataan yang dihilangkan karena semua butir pernyataan benar memiliki $\mathrm{r}$ hitung $>\mathrm{r}$ tabel.

\section{Uji Validitas Variabel Reliabilitas Laporan Audit (Y)}

Hasil olah data untuk uji validitas untuk Reliabilitas Laporan Audit dapat disajikan pada tabel berikut : 


\section{Hasil Uji Validitas Reliabilitas Laporan Audit Item-Total Statistics}

\begin{tabular}{|l|r|r|r|r|}
\hline & $\begin{array}{c}\text { Scale Mean } \\
\text { if Item } \\
\text { Deleted }\end{array}$ & $\begin{array}{c}\text { Scale } \\
\text { Variance if } \\
\text { Item } \\
\text { Deleted }\end{array}$ & $\begin{array}{c}\text { Corrected } \\
\text { Item-Total } \\
\text { Correlation }\end{array}$ & $\begin{array}{c}\text { Cronbach's } \\
\text { Alpha if } \\
\text { Item Deleted }\end{array}$ \\
\hline P1_RLA & 20,057 & 9,214 &, 594 &, 708 \\
P2_RLA & 20,271 & 9,331 &, 510 &, 738 \\
P3_RLA & 20,029 & 10,318 &, 455 &, 767 \\
Reliabilitas Laporan & 12,071 & 3,314 & 1,000 &, 434 \\
Audit & & & & \\
\hline
\end{tabular}

Sumber: Data output SPSS 21, 2016.

Berdasarkan hasil output SPSS di atas, dapat dijelaskan bahwa kolom Corrected ItemTotal Correlation merupakan $\mathrm{r}$ hitung untuk masing-masing item atas butir pernyataan. Dari analisis output di atas, menunjukkan bahwa semua butir pernyataan yaitu pernyataan 1-3 dinyatakan valid dan tidak ada butir pernyataan yang dihilangkan karena semua butir pernyataan benar memiliki $r$ hitung $>r$ tabel.

\section{Uji Asumsi Klasik}

Sebelum dilakukan analisis regresi terhadap variabel-variabel penelitian terlebih dahulu dilakukan uji asumsi klasik. Tujuannya adalah agar data yang digunakan layak dijadikan sumber dan dapat dihasilkan kesimpulan yang benar.

\section{Uji Normalitas}

Berdasarkan hasil output SPSS untuk menguji normalitas data dapat di lihat dari Tabel di bawah ini

Hasil Uji Kolmogorov-Smirnov Test One-Sample Kolmogorov-Smirnov Test

\begin{tabular}{|ll|r|r|r|}
\hline & $\begin{array}{c}\text { Penerapan } \\
\text { Standar } \\
\text { Auditing }\end{array}$ & $\begin{array}{c}\text { Etika Profesi } \\
\text { Auditor }\end{array}$ & $\begin{array}{c}\text { Reliabilitas } \\
\text { Laporan } \\
\text { Audit }\end{array}$ \\
\hline $\mathrm{N}$ & Mean & 71,400 & 70 & 70 \\
Normal Parameters & Std. & 3,7393 & 5,5606 & 12,071 \\
& Deviation &, 085 & 1,8203 \\
Most Extreme & Absolute &, 085 &, 107 &, 141 \\
Differences & Positive &,- 071 &,- 089 &, 130 \\
Kolmogorov-Smirnov Z &, 715 &, 898 & 1,141 \\
Asymp. Sig. (2-tailed) &, 686 &, 396 &, 121 \\
\hline
\end{tabular}


Dari tabel di atas diperoleh hasil Asymp, Sig. (2-tailed) untuk variabel Penerapan Standar Auditing $(\mathrm{X} 1)=0,686>0,05$, Etika Profesi Auditor $(\mathrm{X} 2)=0,396>0,05$ dan Reliabilitas Laporan Audit $(\mathrm{Y})=0,121>0,05$, maka dapat disimpulkan bahwa data residual berdistribusi normal.

\section{Uji Multikolonieritas}

Uji multikolonieritas bertujuan untuk menguji apakah model regresi ditemukan adanya variabel bebas (Independent Variabel). Model regresi yang baik seharusnya tidak terjadi korelasi diantara variabel independen. Metode yang digunakan pada uji multikoleniaritas dalam penelitian ini adalah dengan melihat nilai Tolerance dan Variance Inflation Factor (VIF) pada table Coefficients, apabila nilai Variance Inflation Factor (VIF) output mempunyai nilai VIF kurang dari 10 dan nilai Tolerance output mempunyai nilai tolerance lebih dari 0,10. Hal ini dapat dilihat pada tabel 4.15 dibawah ini:

Hasil Uji Multikolonieritas
Coefficients $^{\mathbf{a}}$
\begin{tabular}{|l|r|r|}
\hline Model & \multicolumn{2}{|c|}{ Collinearity Statistics } \\
\cline { 2 - 4 } & Tolerance & \multicolumn{1}{c|}{ VIF } \\
\hline \multirow{2}{*}{$\begin{array}{l}\text { (Constant) } \\
\text { Penerapan Standar } \\
\text { Auditing } \\
\text { Etika Profesi Auditor }\end{array}$} &, 749 & 1,335 \\
\hline
\end{tabular}

a. Dependent Variable: Reliabilitas Laporan Audit

Sumber: Data output SPSS 21, 2016.

Hasil output SPSS di atas menunjukkan besarnya nilai Tolerance dan Variance Inflation Factor (VIF) untuk masing-masing variabel independen. Variabel Penerapan Standar Auditing (X1), tolerance $0,749>0,10$ dan VIF $1,335<10$, artinya tidak terjadi multikolinearitas. Variabel Etika Profesi Auditor (X2), tolerance 0,749>0,10 dan VIF 1,335 < 10 , artinya tidak terjadi multikolinearitas.

\section{Uji Heteroskedastisitas}

Uji heteroskedastisitas bertujuan menguji apakah dalam model regresi terjadi ketidaksamaan variance dari residual satu pengamatan ke pengamatan lain.

Dari grafik scatterplot dapat diketahui titik-titik tidak membentuk pola yang jelas, dan titik-titik menyebar di atas dan di bawah angka 0 pada sumbu Y. Jadi dapat disimpulkan bahwa tidak terjadi heteroskedastisitas dalam model regresi

\section{Uji Autokolerasi}

Uji autokorelasi bertujuan menguji apakah dalam model regresi linier ada korelasi antara kesalahan penggangu pada periode $t$-1 (sebelumnya). 


\section{Hasil Uji Autokorelasi \\ Model Summary ${ }^{\text {b }}$}

\begin{tabular}{|l|r|r|r|r|r|}
\hline Model & $\mathrm{R}$ & $\mathrm{R}$ Square & $\begin{array}{c}\text { Adjusted R } \\
\text { Square }\end{array}$ & $\begin{array}{c}\text { Std. Error of } \\
\text { the Estimate }\end{array}$ & $\begin{array}{l}\text { Durbin- } \\
\text { Watson }\end{array}$ \\
\hline 1 &, $406^{\mathrm{a}}$ &, 165 &, 140 & 1,6880 & 2,081 \\
\hline
\end{tabular}

Dari tabel terlihat nilai DW yang dihasilkan dari model regresi adalah 2,081. Karena nilai DW yang dihasilkan sebesar 2,081 terletak antara du sebesar 1,672 dan (4-du) sebesar 2,328, maka hipotesis nol diterima, yang berarti tidak ada autokolerasi baik positif maupun negatif.

\section{Analisis Regresi Linier Berganda}

Regresi digunakan untuk mengukur besarnya pengaruh variabel independen (variabel bebas) terhadap variabel dependen (variabel terikat) dan memprediksi variabel dependen dengan menggunakan variabel independen

\section{Hasil Uji Analisis Linier Berganda Coefficients $^{\mathrm{a}}$}

\begin{tabular}{|c|c|c|c|c|c|}
\hline \multirow[t]{2}{*}{ Model } & \multicolumn{2}{|c|}{$\begin{array}{l}\text { Unstandardized } \\
\text { Coefficients }\end{array}$} & \multirow{2}{*}{$\begin{array}{c}\begin{array}{c}\text { Standardize } \\
\mathrm{d} \\
\text { Coefficient } \\
\mathrm{s}\end{array} \\
\text { Beta }\end{array}$} & \multirow[t]{2}{*}{$\mathrm{T}$} & \multirow[t]{2}{*}{ Sig. } \\
\hline & B & $\begin{array}{c}\text { Std. } \\
\text { Error }\end{array}$ & & & \\
\hline (Constant) & 1,345 & 3,141 & & ,428 & ,670 \\
\hline $\begin{array}{l}\text { Penerapan Standar } \\
\text { Auditing }\end{array}$ & ,133 & ,063 & ,274 & 2,124 & 037 \\
\hline $\begin{array}{l}\text { Etika Profesi } \\
\text { Auditor }\end{array}$ & ,063 & ,042 & 193 & 1,494 & 140 \\
\hline
\end{tabular}

a. Dependent Variable: Reliabilitas Laporan Audit

Sumber: Data output SPSS 21, 2016. berikut :

Dari tabel di atas dapat diketahui model persamaan regresi linier berganda sebagai

$\mathrm{Y}=\alpha+\beta 1 \mathrm{X} 1+\beta 2 \mathrm{X} 2+\varepsilon$

$\mathrm{Y}=1,345+0,133 \mathrm{X} 1+0,063 \mathrm{X} 2+\varepsilon$

Keterangan:

$\mathrm{Y}=$ Reliabilitas Laporan Audit

$\alpha=$ Nilai Konstanta

$\beta=$ Koefisien Regresi (nilai peningkatan (+) atau penurunan (-) variabel Y)

$\mathrm{X} 1$ = Penerapan Standar Auditing

$\mathrm{X} 2$ = Etika Profesi Auditor

$\varepsilon \quad=$ Error dan atau faktor lainnya 


\section{Hasil Uji t}

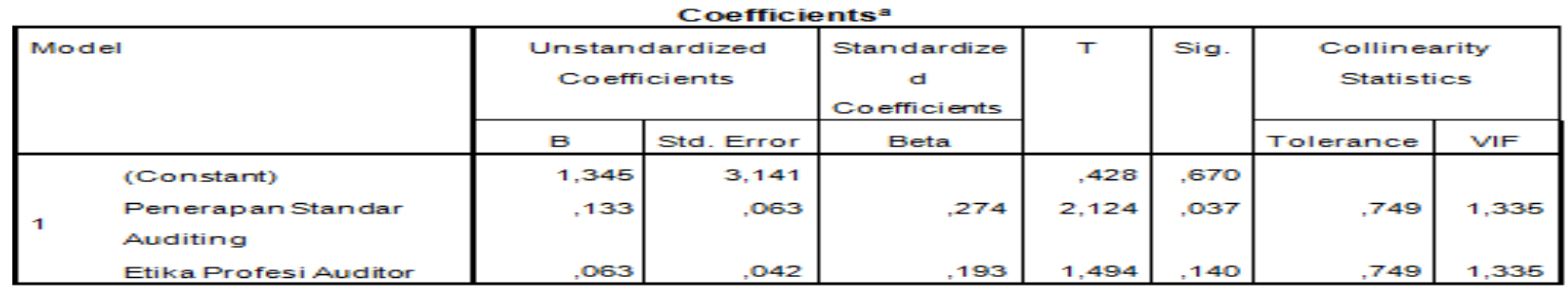

a. Dependent Variable: Reliabilitas Laporan Audit

Berdasarkan pada hasil uji t dalam tabel tersebut maka dapat diketahui bahwa variabel penerapan standar auditing memiliki $\mathrm{t}_{\text {hitung }}>\mathrm{t}$ tabel sehingga, H0 ditolak Ha diterima. Hal ini menyimpulkan bahwa penerapan standar auditing berpengaruh secara signifikan terhadap reliabilitas laporan audit. Sedangkan untuk variabel etika profesi auditor memiliki $\mathrm{t}$ hitung $<\mathrm{t}$ tabel sehingga, H0 diterima Ha ditolak. Hal ini menyimpulkan bahwa variabel etika profesi auditor tidak berpengaruh secara signifikan terhadap reliabilitas laporan audit.

\begin{tabular}{|c|c|c|c|c|c|c|}
\hline \multicolumn{7}{|c|}{$\underset{A^{\prime} O A^{a}}{\text { Hasil uji }} \mathbf{F}$} \\
\hline Model & & Sum of Squares & Df & Mean Square & $\mathrm{F}$ & Sig. \\
\hline \multirow{3}{*}{1} & Regression & 37,742 & 2 & 18,871 & 6,623 & $.002^{\circ}$ \\
\hline & Residual & 190,901 & 67 & 2,849 & & \\
\hline & Total & 228,643 & 69 & & & \\
\hline
\end{tabular}

Berdasarkan hasil uji $\mathrm{F}$ maka dapat diketahui bahwa $\mathrm{F}_{\text {hitung }}>\mathrm{F}$ tabel sehingga $\mathrm{H} 0$ ditolak Ha diterima. Hal ini menyimpulkan bahwa penerapan standar auditing dan etika profesi auditor berpengaruh signifikan terhadap reliabilitas laporan audit secara simultan.

Selanjutnya hasil uji koefisien determinasi menujukkan bahwa:

\begin{tabular}{|l|r|r|r|r|r|}
\hline Model & $R$ & $R$ Square & $\begin{array}{c}\text { Adjusted R } \\
\text { Square }\end{array}$ & $\begin{array}{c}\text { Std. Error of the } \\
\text { Estimate }\end{array}$ & Durbin-Watson \\
\hline 1 &, $406^{\mathrm{a}}$ &, 165 &, 140 & 1,6880 & 2,081 \\
\hline
\end{tabular}

a. Predictors: (Constant), Etika Profesi Auditor, Penerapan Standar Auditing

b. Dependent Variable: Reliabilitas Laporan Audit

Berdasarkan hasil uji koefisien determinasi dapat diketahui bahwa Adjusted $R$ square sebesar 0,140 atau 14\%. Hal ini menunjukkan bahwa masih banyak faktor-faktor lain yang mempengaruhi reliabilitas laporan audit selain penerapan standar auditing dan etika profesi auditor.

\section{Pembahasan dan Interprestasi} Hasil Penelitian Dengan Landasan Teori

\section{Standar auditing berpengaruh terhadap realibilitas laporan audit}

Standar auditing meliputi standar umum yang menekankan pada pentingnya kualitas pribadi yang harus dimiliki auditor, standar pekerjaan lapangan yang menyangkut pengumpulan bukti dan aktivitas lain selama pelaksanaan audit yang sebenarnya dan standar 
pelaporan mengharuskan auditor menyiapkan laporan keuangan secara keseluruhan, termasuk pengungkapan informatif yang telah ditetapkan dan disahkan oleh Institut Akuntan Publik Indonesia harus di terapkan guna menghasilkan laporan audit yang berkualitas dan memiliki keandalan.

Penerapan standar auditing merupakan hal yang sudah seharusnya dilakukan oleh auditor dalam melakukan audit atas laporan keuangan. Diterapkannya standar auditing dapat memberikan pengaruh yang positif terhadap tingkat reliabilitas atau keandalan dari laporan audit yang dihasilkannya.

\section{Etika Profesi Auditor Tidak Berpengaruh Secara Signifikan Terhadap Reliabilitas Laporan Audit}

Tidak berpengaruh secara signifikannya variabel etika profesi dalam penelitian ini kemungkinan diakibatkan karena responden dalam penelitian ini sebagian besar merupakan senior dan junior auditor. Senior dan junior auditor lebih mengutamakan proses audit secara teknis dimana penerapan standar auditing lebih diutamakan dibandingkan dengan etika profesi. Kemungkinan ini diperkuat melalui beberapa indikator dalam variabel etika profesi diantaranya ancaman dan pencegahan serta penyelesaian masalah terkait etika profesi yang pada umumnya dilakukan oleh supervisor dan jabatan di atasnya, pelaksanaan audit atas laporan keuangan selalu dilakukan perencanaan audit dan supervisi yang diharapkan dapat mengurangi bahkan menghilangkan ancaman dan permasalahan yang terkait etika profesi yang mungkin timbul dalam pelaksanaan audit tersebut.

\section{KESIMPULAN DAN SARAN}

\section{Kesimpulan}

Berdasarkan hasil penelitian mengenai pengaruh penerapan standar auditing dan etika profesi auditor terhadap reliabilitas laporan audit yang dilakukan pada Kantor Akuntan Publik di wilayah Jakarta Selatan, maka diperoleh kesimpulan hasil analisis terhadap hipotesa pertama, kedua, dan ketiga sebagai berikut :

1. Penerapan standar auditing berpengaruh secara signifikan dan memiliki nilai positif terhadap reliabilitas laporan audit.

2. Etika profesi auditor tidak berpengaruh secara signifikan namun memiliki nilai positif terhadap reliabilitas laporan audit.

3. Penerapan standar audit dan etika profesi auditor secara simultan mempunyai pengaruh yang signifikan dan memiliki nilai positif terhadap reliabilitas laporan audit.

\section{Saran}

Harapan peneliti untuk penelitian selanjutnya diharapkan dapat memperbaiki kekurangan-kekurangan penelitian ini diantaranya:

1. Sebaiknya melakukan penelitian di luar jam sibuk auditor yaitu selain bulan November sampai Maret.

2. Melakukan penelitian dalam lingkup yang lebih luas dengan waktu yang cukup sehingga dapat diperoleh data yang cukup dan hasil analisa akan jauh lebih akurat. 
3. Hasil penelitian ini hanya dapat mengidentifikasikan pengaruh penerapan standar auditing dan etika profesi auditor secara simultan sebesar 14\%, dan sisanya sebesar $86 \%$ diduga berasal dari faktor lainnya di luar model penelitian diantaranya jumlah klien yang diudit secara bersamaan, lamanya waktu audit, kelengkapan bukti audit, supervisi dan lain sebagainya juga turut mempengaruhi reliabilitas laporan audit, dan dapat digunakan sebagai referensi bagi peneliti selanjutnya. Hal ini sangat menarik untuk dilakukan penelitian lanjutan untuk membuktikan dugaan tersebut dengan responden yang lebih besar lagi.

4. Peneliti menyarankan agar peneliti berikutnya memperoleh data tidak hanya dengan menggunakan kuesioner, namun juga dengan instrumen lain seperti wawancara, pengamatan, dan lainnya.

\section{DAFTAR PUSTAKA}

Agus Supriyanto. 2007. Izin Akuntan PT Kereta Api Dibekukan. http://bisnis.tempo.co/read/news/2007/08/03/056104906/izin-akuntan-pt-kereta-apidibekukan. Diakses : 23 Oktober 2015.

Arens, Alvin A. Randal J, Elder. Mark Beasley. et.al. 2013. Jasa Audit dan Assurance. Buku 1. Jakarta: Salemba Empat.

Erni Riswandari. 2008. Pengaruh Penerapan Standar Audit Terhadap Reliabilitas Laporan Audit. Jurnal Akuntansi Bisnis. Penerbit Universitas Bunda Mulia Jurusan Akuntansi.

Ikatan Akuntan Indonesia. 2009. Standar Akuntansi Keuangan. Jakarta: Salemba Empat.

Imam Ghozali. 2013. Aplikasi Analisis Multivariate Dengan Program IBM SPSS 21. Edisi 7. Semarang: Universitas Diponegoro.

Institut Akuntan Publik Indonesia. 2011. Standar Profesional Akuntan Publik. Jakarta: Salemba Empat.

Jusuf Soewadji. 2012. Pengantar Metodologi penelitian. Jakarta: Mitra Wacana Media.

Kieso, Donald E. Jerry J Weygandt. Terry D Warfield. 2002. Akuntansi Intermediate. Buku 1, edisi 5. Jakarta: Salemba Empat.

Kurniasih Budi dan Anton Apriyanto. 2006. Laporan Keuangan Kereta Api Diduga Salah. http://bisnis.tempo.co/read/news/2006/08/07/05681332/ laporan-keuangan-kereta-apididuga-salah. Diakses : 23 Oktober 2015.

Mulyadi. 2002. Auditing. Buku 1, edisi 6. Jakarta: Salemba Empat.

Priyatno, Duwi. 2012. Belajar Cepat Olah Data Statistik Dengan SPSS. Yogyakarta: CV Andi Offset.

Riduwan dan Engkos Ahmad kuncoro. 2007. Cara Menggunakan dan Memakai Analisis Jalur (Path Analysis). Bandung: CV Alfabeta.

Sugiyono. 2010. Statistika Untuk Penelitian. Bandung: CV Alfabeta.

Sugiyono. 2011. Metode Penelitian Kuantitatif, Kualitatif dan R\&D. Bandung: CV Alfabeta.

Sukrisno Agoes. 2012. Auditing : Petunjuk Praktis Pemeriksaan Akuntan Publik. Buku 1, edisi 4. Jakarta: Salemba Empat.

Stice, Earl K. James D Stice. K Fred Skousen. 2009. Accounting Intermediate. Buku 1, edisi 16. Jakarta: Salemba Empat. 